\title{
The response of broiler breeder hens to dietary balanced protein
}

\author{
E. Steenhuisen ${ }^{2}$ \& R.M. Gous ${ }^{1 \#}$ \\ ${ }^{1}$ School of Agricultural, Earth and Environmental Sciences, University of KwaZulu-Natal, Pietermaritzburg, South Africa \\ ${ }^{2}$ Animal Nutrition Group, Department of Animal Sciences, Wageningen University, Wageningen, The Netherlands
}

(Received 25 April 2016; Accepted 15 July 2016; First published online 26 August 2016)

\begin{abstract}
Copyright resides with the authors in terms of the Creative Commons Attribution 2.5 South African Licence.
See: http://creativecommons.org/licenses/by/2.5/za

Condition of use: The user may copy, distribute, transmit and adapt the work, but must recognise the authors and the South African Journal of Animal Science
\end{abstract}

\begin{abstract}
Two basal feeds (118 and $175 \mathrm{~g}$ protein $/ \mathrm{kg}$ ) with similar balanced amino acid mixtures were appropriately blended to produce six experimental diets differing in protein. These were fed for six weeks to 180 broiler breeder hens (Ross 308) housed in individual cages from $26 \mathrm{w}$ of age. A $13 \mathrm{~h}$ photoperiod was applied. Half the birds were restricted to $160 \mathrm{~g}$ of feed/d, whilst the others were fed ad libitum. The treatments were randomly allocated within six blocks. At the end of the six-week period the mean voluntary intake of the ad libitum-fed birds was $169 \mathrm{~g} / \mathrm{d}$ whereas the intake of hens on feed restriction was $155 \mathrm{~g} / \mathrm{d}$. In spite of the range of protein intakes from 18.5 and $28.8 \mathrm{~g} / \mathrm{bird}$, no differences were observed in rate of laying between the two feeding strategies or dietary protein levels, nor were there differences in the proportions of yolk or albumen between these treatments. Egg weight, egg output and weight gain increased with protein intake as did energy retention $(\mathrm{kJ} / \mathrm{d})$ whereas heat output $(\mathrm{kJ} / \mathrm{d})$ decreased as protein intake increased. Even though dietary protein intake had no effect on rate of lay, the resultant decrease in heat output at high protein intakes suggests that this might be a useful strategy to consider for overcoming mild heat stress.
\end{abstract}

Keywords: Ad libitum feeding, heat production, energy retention, egg composition

${ }^{\#}$ Corresponding author: gous@ukzn.ac.za

\section{Introduction}

Empirical experimental evidence about the relationship between dietary protein supply and broiler breeder productivity is variable in quantity and applicability (Fisher \& Gous, 2009). Yet, to determine the amount and quality of protein to be supplied to a flock of broiler breeders daily to ensure that they are supplied with sufficient amino acids to meet their requirements for optimum protein deposition, accurate estimates of the response of broiler breeder hens to protein supply are needed. The partitioning of protein consumed by the hen between egg output, body weight gain and heat production, especially under limiting conditions, is one of the more important empirical issues that deserves attention.

Flocks of broiler breeder hens are generally allocated a fixed amount of feed daily, calculated to provide them with an optimum amount of each of the essential nutrients and energy to support egg production close to the potential for the flock. Difficulties arise when restricting feed intake in this way even though feeding systems used in such circumstances have been designed to distribute the feed evenly amongst the hens in the flock such that intake is similar amongst all individuals. For example, birds differ in aggressiveness (Mench, 2002) and some will attempt to consume more than the average allocation. Under some circumstances, egg output by the more productive hens may be constrained by the amount of nutrients supplied, whilst in other cases hens may not consume their daily allocation, for example under very hot conditions or when the hen is moulting and is no longer in lay. To make progress in understanding how broiler breeders apportion the limited amount of feed between egg output and growth, between rate of laying and egg weight, and between yolk and albumen production, it is necessary to measure such responses using individually-caged hens. Such experiments have been reported previously (Pearson \& Herron, 1981; 1982; Bowmaker \& Gous, 1991; Nonis \& Gous, 2006; 2012) and the results have provided a valuable insight into the response of broiler breeders to protein and energy.

The primary response of hens to dietary protein is in feed intake, which increases as the dietary protein content becomes marginally deficient, but then drops off markedly as the protein deficiency becomes more severe (Pilbrow \& Morris, 1974; Gous et al., 1987; among others). This has an effect on the ovulatory cycle: egg production does not cease, but becomes increasingly intermittent as the dietary protein supply is reduced (Morris \& Gous, 1988). Egg weight is also influenced by the change in protein intake (Bowmaker \& 
Gous, 1991), as is the composition of yolk and albumen in the egg (Novak et al. 2006). Morris \& Gous (1988) analysed the relative changes in rate of lay and egg weight and showed that rate of lay is influenced to a greater extent by a decrease in protein intake than is egg weight. This has important implications for broiler breeders where the marginal revenue for breeder eggs is considerably higher than is the case with commercial eggs. The difficulty in modelling such a response is in being able to predict the extent to which feed intake will change with dietary protein content, and to understand the mechanism that makes it possible for the hen to continue to lay at such irregular intervals. The difficulty is increased because feed intake is restricted in broiler breeders so they have no chance of overcoming the deficiency on marginally deficient feeds by increasing feed intake. Partitioning the intake of dietary protein under such circumstances becomes even more complex. Only by housing the birds individually and measuring their response to a decreasing protein supply can feed intake, egg output and composition and body weight gain be accurately measured and analysed.

The objective of this trial was therefore to compare the response of broiler breeder hens fed a range of dietary protein contents, either ad libitum or on a restricted basis, with a view to gaining an insight into the way in which such hens would partition the limiting or excess protein consumed between egg output, weight gain and heat production. The responses measured were feed intake, rate of laying, egg weight, egg composition and body weight gain, and these measurements were used to calculate the energy retention and heat production of the hens.

\section{Materials and Methods}

Ethical approval was granted for this trial (Reference 091/13/Animal) by the Animal Ethics Research Committee of the University of KwaZulu-Natal.

For this experiment 200 broiler breeder pullets (Ross 308) were purchased from a local commercial broiler breeder farm at 20 weeks of age and housed in individual cages. Each cage was supplied with an individual feed trough and a wooden perch. All birds had ad libitum access to water via nipple drinkers. A ventilation system supplied fresh air to the birds but was unable to control the climate inside the barn which was therefore influenced by the prevailing weather conditions. A $13 \mathrm{~h}$ photoperiod was applied (Lewis et al., 2010).

Each pullet received $100 \mathrm{~g} / \mathrm{d}$ of a commercial broiler grower feed on arrival. This was increased by 10 $\mathrm{g} / \mathrm{d}$ each week, to reach $160 \mathrm{~g} / \mathrm{d}$ at the start of the experiment, when birds were $26 \mathrm{w}$ old. A total of 180 birds was used for the trial, with 90 being fed ad libitum and the other 90 being restricted to $160 \mathrm{~g} / \mathrm{d}$.

Two basal feeds, one containing 175 and the other $118 \mathrm{~g}$ protein $/ \mathrm{kg}$ (Table 1) were formulated to contain similar balanced amino acid mixtures based on the Aviagen (2014) recommendations for Ross 308 hens. These basal diets were appropriately blended to produce the six experimental diets used (Table 2). All diets were fed in a mash form. The 180 hens used in the trial were randomly assigned to 12 treatment groups comprising six dietary protein levels and two feeding strategies, thus 15 birds were allocated to each treatment. The treatments were randomly allocated within six blocks.

The amount of feed allocated each day to hens on the restricted treatments was measured volumetrically, the size of the containers being adjusted for the specific volume of each diet.

Each bird was weighed on the first day of the experiment and again after three and six weeks, in order to calculate weight gain. Feed intake was measured daily by weighing back feed remaining in each feed trough every day before feeding. Egg production was recorded daily and the weights of all eggs laid on three days a week were measured. On one day a week, the weights of yolk, albumen and shell were measured separately on nine eggs from each of the 12 treatments. The yolk weight was measured after it had been separated from the albumen and rolled on paper towel in order to remove the adhering albumen. Shells were air dried and stored overnight before being weighed. Albumen weight was calculated as the difference between egg weight and the weight of the yolk plus shell.

Mean daily rates of energy retention during the final three weeks of the trial were calculated by adding together the energy required for egg production and for body weight gain. It was assumed that the hens used $8.4 \mathrm{~kJ} \mathrm{ME} / \mathrm{g}$ egg output and $20 \mathrm{~kJ}$ ME/g body weight gain (Emmans, 1974). Mean daily egg output per hen was thus multiplied by $8.4 \mathrm{~kJ} / \mathrm{g}$ and added to the mean body weight gain multiplied by $20 \mathrm{~kJ} / \mathrm{g}$. Mean daily heat loss by the hen $(\mathrm{kJ} / \mathrm{d}$ ) was calculated as the difference between the ME intake (food intake $x$ dietary ME content, $\mathrm{kJ} / \mathrm{d}$ ) and that retained in the egg and the body.

Analysis of the data was performed with the statistical program, GenStat (2011). A general analysis of variance was used to obtain means and standard deviations for the different treatment groups for each week of data collection. Linear regression with groups was used to describe the responses measured to dietary protein as well as to compare these responses between ad libitum- and restricted-fed birds. 
Table 1 Composition of the two basal feeds used in the trial

\begin{tabular}{lcc}
\hline Ingredient & $\begin{array}{c}\text { High protein } \\
(\mathbf{g} / \mathbf{k g})\end{array}$ & $\begin{array}{c}\text { Low protein } \\
\text { (g/kg) }\end{array}$ \\
\hline Maize & 655 & 443 \\
Wheat bran & & 347 \\
Soybean 48 & 245 & 55.3 \\
DL methionine & 2.20 & \\
Vitamin + mineral premix & 1.50 & 1.50 \\
Limestone & 60.6 & 63.7 \\
Salt & 1.60 & 1.60 \\
Monocalcium phosphate & 6.80 & \\
Sodium bicarbonate & 6.20 & 5.80 \\
Oil - sunflower & 21.3 & 81.7 \\
Composition (calculated) & & \\
AMEn (MJ/kg) & 12.0 & 12.0 \\
Crude protein & 175 & 118 \\
Lysine & 7.70 & 4.00 \\
Methionine & 4.50 & 1.70 \\
Methionine + cysteine & 6.60 & 3.30 \\
Threonine & 5.70 & 3.40 \\
Tryptophan & 1.60 & 1.10 \\
Arginine & 10.4 & 6.20 \\
Isoleucine & 6.70 & 3.60 \\
Valine & 7.30 & 4.60 \\
Calcium & 25.0 & 25.0 \\
Available phosphorus & 2.50 & 2.50 \\
& &
\end{tabular}

Table 2 Blending proportions and dietary crude protein (DCP) content of the experimental diets produced from the two basal feeds (Table 1)

\begin{tabular}{lccc}
\hline Treatment & High protein & Low protein & $\begin{array}{c}\text { DCP } \\
(\mathbf{g} / \mathbf{k g})\end{array}$ \\
\hline 1 & 1.0 & 0.0 & 175 \\
2 & 0.8 & 0.2 & 164 \\
3 & 0.6 & 0.4 & 152 \\
4 & 0.4 & 0.6 & 141 \\
5 & 0.2 & 0.8 & 129 \\
6 & 0.0 & 1.0 & 118 \\
\hline
\end{tabular}

Analysis of the data was performed with the statistical program, GenStat (2011). A general analysis of variance was used to obtain means and standard deviations for the different treatment groups for each week of data collection. Linear regression with groups was used to describe the responses measured to dietary protein as well as to compare these responses between ad libitum- and restricted-fed birds.

\section{Results}

During the first week of the experiment daily feed intake in the ad libitum-fed group averaged 217 $\mathrm{g} / \mathrm{bird}$ but decreased over the following weeks (Table 3 ) at a rate of $7.1( \pm 0.61) \mathrm{g}$ per week, or $1 \mathrm{~g} / \mathrm{d}$ over the 
six week period. At the end of this period the mean voluntary intake of the ad libitum-fed birds was $169 \mathrm{~g} / \mathrm{d}$ whereas the intake of hens on feed restriction was $155 \mathrm{~g} / \mathrm{d}$. The rate of decline in feed intake in the $\mathrm{ad}$ libitum-fed hens was the same irrespective of the dietary protein content of the feed offered. This was not the case with the hens whose feed intake was restricted: the greatest decrease in feed intake over the sixweek period was among hens given the highest protein feed $(-2.0 \pm 0.035 \mathrm{~g} /$ week) followed by those on 164 and $118 \mathrm{~g}$ protein $/ \mathrm{kg}$ feed. Restricted-fed hens on the marginally deficient feed protein levels (129 to 152 $\mathrm{g} / \mathrm{kg}$ ) consumed all the feed offered to them.

Table 3 Mean weekly feed intake ( $\mathrm{g} / \mathrm{d})$ for ad libitum-fed and feed restricted breeder hens and the mean intake over the last three weeks of the trial

\begin{tabular}{|c|c|c|c|c|c|c|c|}
\hline \multirow{2}{*}{$\begin{array}{l}\text { Dietary protein } \\
\text { g/kg }\end{array}$} & \multicolumn{6}{|c|}{ Age, weeks } & \multirow{2}{*}{$\begin{array}{c}\text { Mean } \\
31-33 w\end{array}$} \\
\hline & 28 & 29 & 30 & 31 & 32 & 33 & \\
\hline & Ad libitum & & & & & & \\
\hline 118 & 216 & 195 & 188 & 197 & 181 & 164 & 181 \\
\hline 129 & 216 & 189 & 176 & 186 & 181 & 172 & 180 \\
\hline 141 & 218 & 186 & 179 & 190 & 180 & 173 & 181 \\
\hline 152 & 226 & 178 & 165 & 184 & 175 & 172 & 177 \\
\hline 164 & 217 & 180 & 171 & 181 & 176 & 170 & 176 \\
\hline 175 & 206 & 168 & 159 & 173 & 158 & 163 & 165 \\
\hline \multirow[t]{2}{*}{ Mean } & 217 & 183 & 173 & 185 & 175 & 169 & 176 \\
\hline & Restricted & & & & & & \\
\hline 118 & 160 & 159 & 158 & 159 & 157 & 153 & 156 \\
\hline 129 & 160 & 160 & 160 & 160 & 160 & 159 & 160 \\
\hline 141 & 160 & 160 & 160 & 160 & 159 & 158 & 159 \\
\hline 152 & 160 & 160 & 161 & 160 & 160 & 159 & 159 \\
\hline 164 & 158 & 159 & 157 & 158 & 156 & 152 & 155 \\
\hline 175 & 158 & 159 & 154 & 157 & 153 & 147 & 152 \\
\hline Mean & 159 & 160 & 158 & 159 & 158 & 155 & 157 \\
\hline $\mathrm{RSD}^{1}$ & 358 & 212 & 168 & 282 & 281 & 277 & 235 \\
\hline
\end{tabular}

${ }^{1}$ Residual standard deviation (164 d.f.)

Mean daily weight gain (Table 4 ) differed between dietary protein levels and an interaction with feeding levels was evident $(P<0.001)$. Restricted-fed hens showed a linear increase in body weight gain of $0.121 \pm 0.036 \mathrm{~g}$ with each $\mathrm{g} / \mathrm{kg}$ increase in dietary protein level, whereas growth rate on ad libitum-fed hens was constant over all protein levels. On the highest dietary protein level, gain was the same for both feeding strategies, but as the dietary protein content decreased the difference in body weight gain between ad libitum- and restricted-fed birds increased, the difference on the lowest protein content being $10.9 \mathrm{~g} / \mathrm{d}(P$ $<0.001)$.

Rate of lay was unchanged $(P>0.05)$ by dietary protein content or by the amount fed (Table 4$)$. Both egg output (Table 4) and egg weight (Table 5) increased with dietary protein content, the rate of increase in each case being the same whether the birds were restricted or allowed ad libitum access to feed. Egg output increased at a rate of $0.092( \pm 0.023) \mathrm{g} /$ bird $\mathrm{d}(P<0.001)$ and egg weight by $0.082( \pm 0.012) \mathrm{g}(P$ $<0.001)$ for each unit increase in dietary protein content. Egg weight was on average $1.854( \pm 0.479) \mathrm{g}$ heavier $(P<0.001)$ in birds fed ad libitum.

Dietary protein intake (Table 4$)$ increased linearly $(0.141 \pm 0.008 \mathrm{~g} / \mathrm{d})$ with protein content in both restricted- and ad libitum-fed birds, the amount consumed averaging $2.8 \pm 0.326 \mathrm{~g}$ protein/d more by the $\mathrm{ad}$ libitum-fed birds.

Albumen and yolk proportions (Table 5 ) in the eggs of hens subjected to the range of dietary protein levels did not differ between treatments $(P>0.05)$. However, mean albumen weight increased from 36.2 to 
$39.6 \mathrm{~g} / \mathrm{egg}$ at a rate of $0.059 \pm 0.009 \mathrm{~g} / \mathrm{egg}(P<0.001)$ with dietary protein content, with the mean weight being $37.7 \mathrm{~g}$ on the restricted treatments and $38.8 \mathrm{~g} / \mathrm{egg}$ on the ad libitum treatments $(P<0.01)$. Yolk weight increased from 17.2 to $18.8 \mathrm{~g} / \mathrm{egg}$ with dietary protein content, at a rate of $0.025 \pm 0.006 \mathrm{~g} / \mathrm{egg}(P<0.001)$, the mean weight being heavier $(18.2 \mathrm{vs} .17 .8 \mathrm{~g})(P<0.05)$ in birds fed ad libitum. The rates of increase in albumen and yolk were the same for both feeding strategies.

Table 4 Mean rate of laying (\%), egg output (g/bird d), dietary protein intake (g/d) and weight gain ( $g / d)$ over the final three weeks of the experimental period in broiler breeder hens subjected to six dietary protein levels and fed either ad libitum or restricted (Restr.)

\begin{tabular}{lcccccccc}
\hline \multirow{2}{*}{ Dietary protein g/kg } & \multicolumn{2}{c}{ Rate of laying, \% } & \multicolumn{2}{c}{ Egg output, g/bird d } & \multicolumn{2}{c}{ Protein intake, g/d } & \multicolumn{2}{c}{ Weight gain, g/d } \\
& Restr. & Ad lib. & Restr. & Ad lib. & Restr. & Ad lib. & Restr. & Ad lib. \\
\hline 118 & 85.1 & 84.5 & 49.3 & 51.6 & 18.5 & 21.3 & 2.7 & 13.6 \\
129 & 90.2 & 84.8 & 54.3 & 52.8 & 20.6 & 23.2 & 5.4 & 14.9 \\
141 & 84.8 & 92.7 & 55.3 & 58.0 & 22.4 & 25.5 & 6.4 & 13.9 \\
152 & 88.3 & 91.7 & 53.7 & 59.3 & 24.2 & 26.9 & 7.5 & 13.9 \\
164 & 86.0 & 89.2 & 56.9 & 57.8 & 25.4 & 28.8 & 9.0 & 17.5 \\
175 & 85.1 & 83.8 & 58.0 & 53.2 & 26.6 & 28.8 & 10.0 & 10.1 \\
\hline Mean & 86.6 & 87.8 & 54.6 & 55.4 & 23.0 & 25.8 & 6.8 & 14.0 \\
\hline RSD & 199 (163 d.f.) & 33.1 (160 d.f.) & $4.91(164$ d.f.) & $44.7(164$ d.f.)
\end{tabular}

${ }^{1}$ Residual standard deviation.

Table 5 Mean egg weight (g) and albumen and yolk proportions (\%) over the final three weeks of the experimental period in broiler breeder hens subjected to six dietary protein levels and fed either ad libitum or restricted

\begin{tabular}{lcccccc}
\hline \multirow{2}{*}{ Dietary protein, g/kg } & \multicolumn{2}{c}{ Egg weight, $\mathbf{g}$} & \multicolumn{2}{c}{ Albumen \% } & \multicolumn{2}{c}{ Yolk \% } \\
& Restr. & Ad lib. & Restr. & Ad lib. & Restr. & Ad lib. \\
\hline \multirow{2}{*}{118} & 57.5 & 59.9 & 61.3 & 61.8 & 29.4 & 29.0 \\
129 & 60.5 & 62.3 & 61.6 & 61.6 & 29.2 & 29.3 \\
141 & 61.3 & 62.6 & 61.5 & 61.5 & 29.3 & 29.1 \\
152 & 61.0 & 64.6 & 61.7 & 62.0 & 29.2 & 29.2 \\
164 & 62.4 & 64.8 & 61.4 & 62.5 & 29.2 & 28.5 \\
175 & 64.2 & 63.6 & 61.7 & 61.4 & 29.2 & 29.6 \\
\hline Mean & 61.1 & 62.9 & 61.6 & 61.8 & 29.2 & 29.1 \\
\hline RSD & 9.85 (160 d.f.) & 2.63 (134 d.f.) & 2.23 (134 d.f.) \\
\hline
\end{tabular}

${ }^{1}$ Residual standard deviation.

The mean daily energy retention increased linearly $(P<0.001)$ with dietary protein content in both the ad libitum- and restricted-fed birds (Table 6). One exception was found on the feed with the highest protein content, in which the ad libitum-fed birds reduced their energy retention to a level similar to that by hens fed the lowest protein feed ad libitum. When comparing the slopes of these linear responses, and excluding the exception mentioned above, the responses to dietary protein were not the same for the two feeding strategies, with retention increasing at half rate in the ad libitum-fed hens compared with those fed on a restricted basis, the latter increasing at $3.79 \pm 0.895 \mathrm{~kJ} / \mathrm{g} / \mathrm{kg}$ protein (Figure 1). Excluding the energy retention by birds on the highest protein diet fed ad libitum, the mean difference in energy retention between the two feeding strategies $(P<0.01)$ was $160 \mathrm{~kJ} / \mathrm{d}$. 
Heat production by birds fed ad libitum was on average $89 \mathrm{~kJ} / \mathrm{d}$ greater than by those whose feed was restricted $(P<0.01)$ (Table 6$)$ and this difference was maintained over all the dietary protein levels used in the trial resulting in parallel linear responses to dietary protein in both feeding strategies (Fig. 1). The rate of decline in heat production with dietary protein was $-3.65( \pm 0.451) \mathrm{kJ} / \mathrm{g} / \mathrm{kg}(P<0.001)$.

Table 6 Mean daily rates of energy retention $(\mathrm{kJ} / \mathrm{bird})$ and heat production $(\mathrm{kJ} / \mathrm{bird})$ over the final three weeks of the experimental period by broiler breeder hens subjected to six dietary protein levels and fed either ad libitum or restricted

\begin{tabular}{lcccccc}
\hline \multirow{2}{*}{ Dietary Protein, g/kg } & \multicolumn{2}{c}{ Energy retained, kJ/d } & \multicolumn{3}{c}{ Heat produced, kJ/d } \\
\cline { 2 - 7 } & Restricted & Ad lib. & Mean & Restricted & Ad lib. & Mean \\
\hline 118 & 467 & 698 & 583 & 1410 & 1491 & 1451 \\
129 & 564 & 742 & 653 & 1351 & 1415 & 1383 \\
141 & 583 & 765 & 674 & 1325 & 1405 & 1365 \\
152 & 601 & 776 & 689 & 1311 & 1348 & 1330 \\
164 & 666 & 787 & 727 & 1223 & 1347 & 1285 \\
175 & 685 & 711 & 698 & 1151 & 1295 & 1223 \\
\hline Mean & 595 & 747 & & 1295 & 1384 \\
\hline \multicolumn{7}{c}{} \\
\hline
\end{tabular}

${ }^{1}$ Residual standard deviation

\section{Discussion}

It is unusual to allow broiler breeder hens ad libitum access to feed, the assumption being that if their intake were not restricted they would greatly overconsume energy and essential nutrients, become obese, and laying would become erratic (Hocking, 2009). The results of this trial suggest otherwise. The rate of laying was the same on the ad libitum and restricted treatments, as was egg output. Following one week in which feed intake was considerably higher than that allocated on a restricted basis (217 vs. $159 \mathrm{~g}$ ) intake by the ad libitum-fed hens declined linearly such that after three weeks they were eating only $15 \mathrm{~g}$ more per day than the restricted hens. This difference remained the same through to the sixth week of the trial. The patterns of intake between the two feeding strategies were also similar: in the final week of the trial the lowest intake was on the highest and the lowest dietary protein level offered, and the highest intakes were on marginally deficient protein feeds.

The small additional daily feed intake by hens fed ad libitum enabled them to maintain a growth rate averaging $14 \mathrm{~g} / \mathrm{d}$ over all protein treatments. None of the restricted-fed birds could achieve this growth rate, the highest $(10 \mathrm{~g} / \mathrm{d})$ being by those hens given the highest protein feed, which equalled that by birds given the same feed ad libitum. This was the lowest growth rate recorded among the ad libitum-fed birds. As there is no advantage in encouraging growth in laying broiler breeders there is some justification for controlling the amount of feed that is allocated to them, but giving them ad libitum access to feed does not lead to a gross overconsumption of protein and energy.

Various estimates of the daily intake of protein required by broiler breeders to support egg production have been made by researchers in the past, these varying from $16.5 \mathrm{~g} / \mathrm{d}$, for individually housed breeders (Pearson \& Herron, 1982) to $22 \mathrm{~g} / \mathrm{d}$ (Waldroup et al., 1976), but these were for breeders whose rates of laying were far lower than the production recorded in this trial. Protein intakes in this trial varied from 18.5 to $28.8 \mathrm{~g} / \mathrm{d}$ with no apparent difference in rate of laying between treatments.

Rate of laying in broiler breeders is highly variable so it is only in cases where large differences between treatments are present that it is likely that such differences will be statistically significant (Morris \& Gous, 1988). In the present trial there appears to be a curvilinear response in rate of laying to dietary protein in the case of the hens fed ad libitum (Table 4) but this proved to be non-significant. Pearson \& Herron (1982) found no differences in rate of laying or egg output when energy supply was adequate, but at the lowest energy allowance they used in their trial, both egg number and egg weight decreased with increasing protein allowance. The low rate of laying on the highest protein feed, when hens had ad libitum access to this feed, was the main cause of the low energy retention recorded on this treatment (Table 6). 

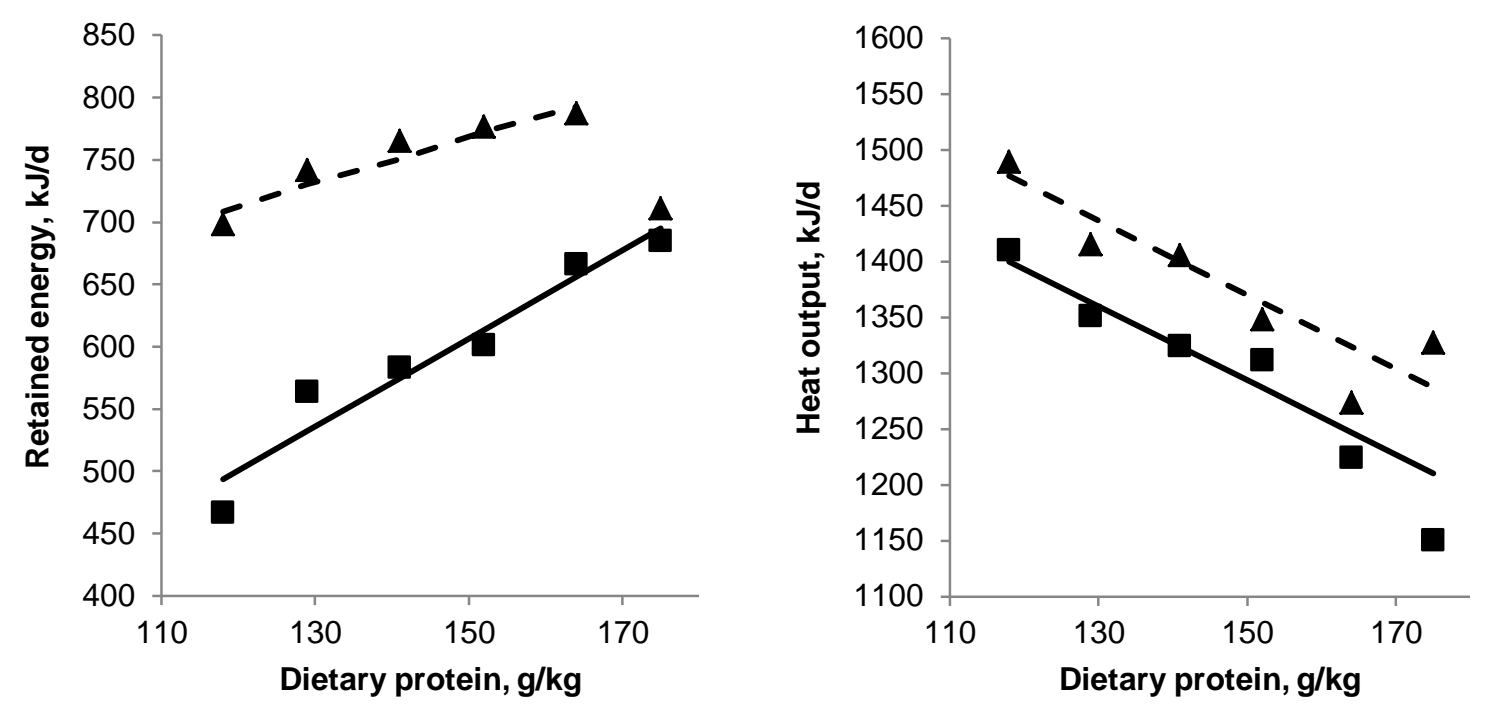

Figure 1 Linear responses in retained energy $(\mathrm{kJ} / \mathrm{bird} \mathrm{d})$ and heat output $(\mathrm{kJ} / \mathrm{bird} \mathrm{d})$ in broiler breeder hens offered feeds of different dietary protein content on either a restricted (solid line) or ad libitum (dashed line) basis.

Rate of lay typically has a coefficient of variation between individual hens of 0.20 to 0.25 , compared with a coefficient of variation of 0.10 for egg weight (Morris \& Gous, 1988) and, consequently, differences in egg weight between treatments are more likely to be observed than differences in rates of laying. Egg weight responded to an increase in protein intake, thus eggs were heavier on the higher protein feeds and on the ad libitum treatments. Interestingly, unlike the report by Novak et al. (2006) the proportions of yolk and albumen in the egg did not change with protein intake so the additional protein intake influenced these components equally. It has been demonstrated that albumen and yolk contents are allometrically related (Johnston \& Gous, 2007; Nonis \& Gous, 2013; Ferreira et al., 2015) which explains why the proportions of the two components remained constant as dietary protein intake was increased.

Because of the increase in egg weight with dietary protein intake egg output increased also, this being at the same rate in hens fed restricted or ad libitum. This increase in egg output together with that in body weight gain resulted in the increase in energy retention with dietary protein content shown in Table 6 and illustrated in Figure 1. The higher energy retention by ad libitum-fed hens than by those fed a restricted amount was due entirely to the higher body weight gain by these birds because the egg outputs were the same with both feeding strategies. As a result of the higher energy retention with dietary protein content the amount of heat that needed to be lost to the environment decreased as the intake of dietary protein increased. The rate of decline in heat production was the same with both feeding strategies, but remained higher throughout the range of protein levels in birds fed ad libitum.

The amount of heat lost (or produced) by a bird is calculated as the difference between the amount of energy consumed and that retained in the egg and body. To remain in thermal balance, the amount of heat that a hen produces, through functions such as maintenance, growth, egg production, digestion and excretion, must equal the amount of heat lost to the environment (Emmans, 1974; Cheng et al., 1997). In laying hens, heat stress depresses body weight, egg production and egg quality (Marsden \& Morris, 1981; Mashaly et al., 2004), and it is the suppression of feed intake that is usually the cause of the decline in production (Payne, 1966; Star et al., 2008). When hens are kept at high temperatures it is imperative therefore that the composition of feed supplied will enable the birds to meet their nutrient requirements at a lower daily feed intake. In this experiment the amount of heat lost decreased with dietary protein content because of the concomitant increase in egg output. Irrespective of the need to increase dietary protein content to counteract the decrease in feed intake as the environmental temperature is increased, as suggested by Payne (1966) and others, higher protein diets or allocations would appear to be an advantage at high temperatures because of the lower heat output resulting from the higher egg output. Nevertheless, as environmental temperatures increase above a critical point the increase in nutrient supply will be insufficient to enable the birds to continue laying at their potential (Marsden \& Morris, 1981) and performance will decrease. 


\section{Conclusions}

Allowing broiler breeders ad libitum access to feed does not lead to a gross overconsumption of protein and energy. The optimum supply of protein to broiler breeder hens remains an economic decision, but even though a daily supply of dietary protein between 18.5 and $28.8 \mathrm{~g} / \mathrm{bird} \mathrm{d}$ had no effect on rate of lay or the proportions of yolk and albumen in the eggs of broiler breeders in this trial, heat output decreased with protein supply, suggesting that this may be a useful strategy to consider in overcoming mild heat stress.

\section{Acknowledgements}

The authors acknowledge the financial contribution for this project from the National Research Foundation and from the Protein Research Foundation.

\section{Authors' Contributions}

Conception and design - RMG; Data collection and analysis - ES; Drafting of paper - ES; Critical revision and final approval of version to be published - RMG

\section{Conflict of Interest Declaration}

The authors certify that they have no affiliations with or involvement in any organization or entity with any financial or non-financial interest in the subject matter or materials discussed in this manuscript.

\section{References}

Aviagen, 2014. http://en.aviagen.com/assets/Tech_Center/Ross_Broiler/Ross308BroilerNutrition Specs2014-EN.pdf (accessed July 2014).

Bowmaker, J.A. \& Gous, R.M., 1991. Response of broiler breeder hens to dietary lysine and methionine. Br. Poult. Sci. 32, 1069-1088.

Cheng, T.K., Hamre, M.L.H. \& Coon, C.N., 1997. Effects of environmental temperature, dietary protein and energy levels on broiler performance. J. Appl. Poult. Res. 6, 1-17.

Emmans, G.C., 1974. The effects of temperature on the performance of laying hens. In: Energy Requirements of Poultry. Eds: Morris, T.R. \& Freeman, B.M., British Poultry Science Ltd., Edinburgh, Scotland. pp. 79-90.

Ferreira, N.T., Sakomura, N.K., Dorigam, J.C.P., da Silva, E.P. \& Gous, R.M., 2015. Modelling the egg components and laying patterns of broiler breeder hens. Anim. Prod. Sci. http://dx.doi.org/10.1071/AN14737

Fisher, C. \& Gous, R.M., 2009. Protein and amino acid responses. In: Biology of Breeding Poultry. Ed: Hocking, P.M., Poultry Science Symposium Series Volume Twenty-nine, CABI International. pp. 331-360.

GenStat, 2011. GenStat Statistical Software, 14th Edition. Lawes Agricultural Trust.

Gous, R.M., Griessel, M. \& Morris, T.R., 1987. Effect of dietary energy concentration on the response of laying hens to amino acids. Br. Poult. Sci. 28, 427-436.

Hocking, P.M., 2009. Feed restriction. In: Biology of Breeding Poultry. Ed: Hocking, P.M., Poultry Science Symposium Series Volume Twenty-nine, CABI International. pp. 307-330.

Johnston, S.A. \& Gous, R.M., 2007. Modelling the changes in the proportions of the egg components during a laying cycle. Br. Poult. Sci. 48, 347-353.

Lewis, P.D., Danisman, R. \& Gous, R.M., 2010. Photoperiods for broiler breeder females during the laying period. Poult. Sci. 89, 108-114.

Marsden, A. \& Morris, T.R., 1981. Egg production at high temperatures. In: Intensive Animal Production in Developing Countries. Eds: Smith, A.J. \& Gunn, R.G., Occasional Publication No. 4 - British Society of Animal Production. pp. 299-309.

Mashaly, M.M., Hendricks, G.L., Kalama, M.A., Gehad, A.E., Abbas, A.O. \& Patterson, P.H., 2004. Effects of heat stress on production parameters and immune responses of commercial laying hens. Poult. Sci. 83, 889-894.

Mench, J.A., 2002. Broiler breeders: feed restriction and welfare. Wrld's Poult. Sci. J. 58, 23-29.

Morris, T.R. \& Gous, R.M., 1988. Partitioning of the response to protein between egg number and egg weight. Br. Poult. Sci. 29, 93-99.

Nonis, M.K. \& Gous, R.M., 2006. Utilisation of synthetic amino acids by broiler breeder hens. S. Afr. J. Anim. Sci. 36, 126-134.

Nonis, M.K. \& Gous, R.M., 2012. Broiler breeders utilise body lipid as an energy source. S. Afr. J. Anim. Sci. 42, 369-378.

Nonis, M.K. \& Gous, R.M., 2013. Modelling changes in the components of eggs from broiler breeders over time. Br. Poult. Sci. 54, 603-610.

Novak, C., Yakout, H.M. \& Scheideler, S.E., 2006. The effect of dietary protein level and total sulfur amino acid:lysine ratio on egg production parameters and egg yield in Hy-line W-98 hens. Poult. Sci. 85, 2195-2206.

Payne, C.G., 1966. Environmental temperature and egg production. In: The Physiology of the Domestic Fowl. Eds: Horton-Smith, C. \& Amorosa, E.C., Edinburgh, Oliver and Boyd. pp. 235-241.

Pearson, R.A. \& Herron, K.M., 1981. Effects of energy and protein allowances during lay on the reproductive performance of broiler breeder hens. Br. Poult. Sci. 22, 227-239.

Pearson, R.A. \& Herron, K.M., 1982. Relationship between energy and protein intakes and laying characteristics in individually-caged broiler breeder hens. Br. Poult. Sci. 23, 145-159. 
Pilbrow, P.J. \& Morris, T.R., 1974. A comparison of lysine requirements amongst eight stocks of laying fowl. Br. Poult. Sci. 15, 51-73.

Star, L., Van den Anker, I. \& Parmentieri, H.K., 2008. Effects of single or combined climatic and hygienic stress in four layer lines: 1. Performance. Poult. Sci. 87, 1022-1030.

Waldroup, P.W., Hazen, K.R., Bussell, W.D. \& Johnson, Z.B., 1976. Studies on the daily protein and amino acid needs of broiler breeder hens. Poult. Sci. 55, 2342-2347. 